\title{
Evaluation of Car Performances Using Data Envelopment Analysis
}

\author{
Yunus GÜRAL ${ }^{1, *}$ and Ayşe Turan BUĞATEKİN ${ }^{I}$ \\ ${ }^{1}$ Department of Statistics, University of Firat, Elazı̆̆, Turkey
}

\begin{abstract}
Data Envelopment Analysis (DEA) is a nonparametric method used to examine the relative efficiencies of Decision Making Units (DMUs) on conditions where there are multiple inputs and multiple outputs. As in all sectors, it is very important for the automotive sector to operate effectively. Therefore, it is also important to measure the efficiency and find the source of the inefficiency. In this study, the performances of the DMU of the automobiles will examine using Data Envelopment Analysis. In this direction, it is aimed to assist consumers in purchasing by calculating the relative efficiencies of automobile models, determining effective and ineffective DMUs according to the wishes of the consumers. Sales price and fuel consumption are determined as input variables; maximum speed, cylinder volume, horsepower, maximum torque, luggage volume, acceleration time from 0 to $100 \mathrm{~km}$ are determined as output variables.
\end{abstract}

\section{Introduction}

In the automotive sector many brands and models are sold to consumers. The features of the automobile are different in these models. In addition to the features of the automobile price, fuel consumption, comfort and safety are also influential in making decisions for the consumers. These criteria have a great influence on consumers' choice.

DEA was first introduced in 1957 by Farrell in the literature and in the following years different researchers tried to be developed. In 1978 Charnes, Cooper and Rhodes studied it in detail [2].

The DMUs should be similar, since measurements are made relatively in the Data Envelopment Analysis. DEA is a method that uses similar inputs to obtain similar outputs.

In this study, the most selling car models in Turkey in 2017 are included. According to the wishes of the consumers it is aimed to assist consumers in purchasing by calculating the relative efficiencies of automobile models and determining effective and ineffective DMUs.

\footnotetext{
*Corresponding author: ygural@,firat.edu.tr
} 


\section{Data Envelopment Analysis}

DEA is a linear programming technique for measuring the relative efficiency of DMUs with multiple inputs and multiple number of outputs. DEA is used in many areas such as Health, Sports, Finance, Tourism, Marketing, Education [1,3]. The advantage of the DEA over other non-parametric methods is that multiple outputs can be measured in the production process. DEA identifies effective and ineffective DMUs. It also provides information on the amount and the source of ineffectiveness of DMUs.

\subsection{Implementation Objectives of DEA}

- Determine the amount and source of inefficiency of ineffective units,

- Creation of a reference set,

- Improving resources by reference set,

- Evaluation of the appropriateness of the administrations.

\subsection{Charnes, Cooper, Rhodes (CCR)}

CCR is the basic DEA model developed by Charnes, Cooper, Rhodes. Input-oriented CCR is concerned with how much input will be reduced to achieve the desired output. The outputoriented CCR is concerned with how much output level will increased by the amount of input available.

\subsubsection{Output-oriented CCR (CCR-O)}

CCR-O is the model that calculates how much increase the amount of output without changing the input level. Output-oriented CCR model [3] as follows

$$
\begin{gathered}
\operatorname{Max}_{k}+\varepsilon \sum_{r=1}^{l} T_{r}^{-}+\varepsilon \sum_{i=1}^{m} T_{i}^{+} \\
T_{r}^{-}+\sum_{j=1}^{t} \lambda_{j k} X_{r j}=X_{r k} \\
-T_{i}^{+}+\sum_{j=1}^{t} \lambda_{j k} Y_{i j}-\beta_{k} Y_{i k}=0 \\
\lambda_{j k}, T_{r}^{-}, T_{i}^{+} \geq 0
\end{gathered}
$$

If $\beta^{*}=1$, DMU is efficient. If $\beta^{*}>1$ or slack variables are not zero, then DMU is inefficient.

For the full efficiency of the DMU, $\beta^{*}=1$ and all slack variables must be zero. If $\beta^{*}=1$ but one of the slack variables is different from zero, it is called weak efficient [4].

For an ineffective DMU to be effective, target values are calculated using the following formula. 


$$
\begin{aligned}
& X_{r k}=X_{r k}-T_{r}^{-*} ; r=1, \ldots, l \\
& Y_{i k}=\beta_{k}^{*} Y_{i k}+T_{i}^{+*} ; i=1, \ldots, m
\end{aligned}
$$

\begin{tabular}{|c|c|c|c|c|c|}
\hline $\begin{array}{l}\text { Segment C } \\
\text { Sedan }\end{array}$ & Efficiency & $\begin{array}{l}\text { Segment C } \\
\text { HB }\end{array}$ & Efficiency & $\begin{array}{l}\text { Segment C } \\
\text { Suv }\end{array}$ & Efficiency \\
\hline Fiat Egea & 1 & VW Golf & 1,01723 & $\begin{array}{l}\text { Nissan } \\
\text { Qashqai }\end{array}$ & 1 \\
\hline $\begin{array}{l}\text { Renault } \\
\text { Megane }\end{array}$ & 1 & Seat Leon & 1 & Dacia Duster & 1 \\
\hline $\begin{array}{l}\text { Toyota } \\
\text { Corolla } \\
\end{array}$ & 1 & $\begin{array}{l}\text { Opel Astra } 1.6 \\
\text { Cdti Enjoy }\end{array}$ & 1 & VW Tiguan & 1 \\
\hline Ford Focus & 1 & $\begin{array}{l}\text { Renault } \\
\text { Megane }\end{array}$ & 1 & $\begin{array}{l}\text { Hyundai } \\
\text { Tucson }\end{array}$ & 1 \\
\hline Opel Astra & 1 & Fiat Egea & 1,00306 & Toyota C-Hr & 1 \\
\hline Honda Civic & 1,01163 & Toyota Auris & 1 & Peugeot 3008 & 1 \\
\hline VW Jetta & 1 & $\begin{array}{l}\text { Audi A3 } \\
\text { Sportback }\end{array}$ & 1 & $\begin{array}{l}\text { Renault } \\
\text { Kadjar }\end{array}$ & 1 \\
\hline Skoda Octavia & 1 & $\begin{array}{l}\text { Bmw 1 serial } \\
116 \mathrm{~d}\end{array}$ & 1 & Ford Kuga & 1 \\
\hline Audi A3 & 1 & $\begin{array}{l}\text { Mercedes A } \\
\text { Serial A180 }\end{array}$ & 1,0192 & $\begin{array}{l}\text { Honda } \\
\text { CR-V }\end{array}$ & 1 \\
\hline $\begin{array}{l}\text { Mercedes } \\
\text { CLA } 180\end{array}$ & 1,02588 & Hyundai İ30 & 1 & Kia Sportage & 1 \\
\hline Mazda 3 & 1,02173 & Nissan Pulsar & 1 & $\begin{array}{l}\text { Mercedes } \\
\text { GLA } 200\end{array}$ & 1 \\
\hline $\begin{array}{l}\text { Mitsubishi } \\
\text { Lancer }\end{array}$ & 1,05338 & Peugeot 308 & 1 & Seat Ateca & 1,022691 \\
\hline & & $\begin{array}{l}\text { Skoda Rapid } \\
\text { Spaceback }\end{array}$ & 1 & Bmw X1 & 1 \\
\hline & & Honda Civic & 1 & $\begin{array}{l}\text { Subaru } \\
\text { Forester } 2 \\
\end{array}$ & 1,048195 \\
\hline & & Ford Focus & 1 & Audi Q3 & 1 \\
\hline & & Volvo V40 & 1 & Subaru XV & 1,058605 \\
\hline & & $\begin{array}{l}\text { Volvo V40 } \\
\text { Cross Country }\end{array}$ & 1,0198 & $\begin{array}{l}\text { Mini } \\
\text { Countryman }\end{array}$ & 1,030307 \\
\hline & & Citroen C4 & 1,0521 & $\begin{array}{l}\text { Range Rover } \\
\text { Evoque }\end{array}$ & 1 \\
\hline & & $\begin{array}{l}\text { Alfa Romeo } \\
\text { Giulietta }\end{array}$ & 1 & Skoda Yeti & 1 \\
\hline & & Kia Cee'd & 1 & $\begin{array}{l}\text { Mitsubishi } \\
\text { ASX }\end{array}$ & 1,026402 \\
\hline & & & & Toyota RAV4 & 1 \\
\hline & & & & Mazda CX-5 & 1 \\
\hline
\end{tabular}

Table 1. Efficiency Values of car model. 
Table 2. Efficiency Values of car model.

\begin{tabular}{|l|l|l|l|}
\hline Segment B & Efficiency & Segment D & Efficiency \\
\hline Toyota Yaris & 1 & VW Passat & 1 \\
\hline VW Polo & 1 & Mercedes C180 & 1 \\
\hline Honda Jazz & 1 & Skoda Superb & 1 \\
\hline Kia Rio & 1,0317 & Opel Insignia & 1 \\
\hline Ford Fiesta & 1 & Audi A4 & 1,00645 \\
\hline Hyundai i20 & 1,0254 & Bmw 318d & 1 \\
\hline Renault Clio & 1 & Renault Talisman & 1 \\
\hline Citroen C3 & 1 & Ford Mondeo & 1,02004 \\
\hline Opel Corsa & 1,04848 & Volvo S60 & 1 \\
\hline Peugeot 208 & 1 & Peugeot 508 & 1 \\
\hline Dacia Sandero & 1 & Toyota Avensis & 1 \\
\hline Nissan Micra & 1 & & \\
\hline Skoda Fabia & 1 & & \\
\hline Mini Cooper & 1 & & \\
\hline $\begin{array}{l}\text { Audi A1 } \\
\text { Sportback }\end{array}$ & 1 & & \\
\hline Suzuki Baleno & 1,0255 & & \\
\hline
\end{tabular}

In Turkey best-selling car models in 2017 were included in the application. According to Table 1 and 2, twenty of these car models are not effective. Target values for ineffective automobile models can be found using (1) and (2).

\section{Conclusion}

Relative efficiency measurement by Data Envelopment Analysis has many application fields in many sectors such as education, bank and health. However, unlike these sectors, it is noteworthy that in the automotive sector there are very few studies in which the relative efficiencies of automobile models are measured using DEA, especially from a consumer point of view. In addition, DEA based decision support system has been created to help automobile consumers make purchasing decisions. It is believed that this aspect of the work contributes to the literature and thus may be a guide to similar work in the future. 


\section{References}

1. Aktaş, H., An Application of Data Envelopment Analysis with financial ratios assess the performance of banks, Yönetim ve Ekonomi, Celal Bayar Üniversitesi, İ.İ.B.F. Dergisi, 5, 27-40, 1999.

2. Charnes, A., Cooper, W.W., Rhodes, E., Measuring the efficiency of decision making units. European Journal of Operational Research 2, 429-444, 1978.

3. Erpolat, S., Veri Zarflama Analizi (Ağırlık Kısıtlamasız, Ağırlık Kısıtlamalı, Şans Kısıtlı, Bulanık) Türkiye'deki Özel Bütçeli Diğer İdarelerin Etkinlik Analizi, Evrim Yayınevi, İstanbul, 2011.

4. Kutlar, A. ve Babacan, A., A Comparison Of The Effectivity Of Cumhuriyet University With State Universities: An Applicatoin Of Dea Technique, Kocaeli Üniversitesi Sosyal Bilimler Enstitüsü Dergisi, 15(1), 148-172, 2008. 